\title{
Strategi Dakwah dan Pencitraan Diri Jemaat Ahmadiyah
}

\author{
Uwes Fatoni ${ }^{1 *}$ \\ ${ }^{1}$ UIN Sunan Gunung Djati Bandung \\ kanguwes@uinsgd.ac.id
}

\begin{abstract}
This study describes the strategy of the propaganda of the Abmadiyah Indonesia (JAI) congregation in facing the resistance of Muslims to create a positive self-image in the community. Using ethnographic studies with da'wah strategy theory, and the dramaturgy theory of this research was carried out in the villages of Tenjowaringin Salawu, and Cipakat Singaparna Tasikmalaya, West Java. The results revealed that the relationship between $J A I$ and the community, especially non-Ahmadiyya Muslims in the villages of Tenjowaringin Salawn and in the Cipakat Village, Tasikmalaya, was quite good. Although there were several explosions caused by provocations from groups outside the community of the two villages, this did not make JAI far from the surrounding community. The propaganda strategy carried out by the Ahmadiyya community was carried out in three activities, namely communication through Rabtab activities, cooperation through charity wikari, and education through the Tarbiyah / School institution. The application of da'wah strategies carried out by $J A I$ was able to shape their positive self-image in the community in accordance with the expectations of the congregation and the management of the Abmadiyya organization.
\end{abstract}

Keywords: Da'wah Strategy, Self Image, Abmadiyah

\begin{abstract}
ABSTRAK
Penelitian ini menggambarkan strategi dakwah jemaat Ahmadiyah Indonesia (JAI) dalam menghadapi resistensi umat Islam untuk menciptakan citra diri positif di masyarakat. Menggunakan studi etnografi dengan teori strategi dakwah, dan teori dramaturgi penelitian ini dilakukan di desa Tenjowaringin Salawu, dan Cipakat Singaparna Tasikmalaya, Jawa Barat. Hasil penelitian mengungkapkan bahwa hubungan JAI dengan masyarakat khususnya umat Islam non-Ahmadiyah di desa Tenjowaringin Salawu maupun di Desa Cipakat Singaparna Tasikmalaya cukup baik. Meskipun beberapa kali muncul letupanletupan yang disebabkan oleh provokasi dari kelompok di luar masyarakat dua desa tersebut, namun hal itu tidak menjadikan JAI menjadi jauh dari masyarakat sekitarnya. Strategi dakwah yang dilakukan jemaat Ahmadiyah dilakukan dalam tiga kegiatan yaitu komunikasi melalui kegiatan Rabtah, kerjasama melalui wikari amal, dan pendidikan melalui lembaga Tarbiyah/Sekolah. Penerapan Strategi dakwah yang dilakukan oleh JAI mampu membentuk citra diri positif mereka di masyarakat sesuai dengan yang diharapkan oleh jemaah maupun pengurus organisasi Ahmadiyah.
\end{abstract}

Kata Kunci: Strategi Dakwah, Citra Diri, Ahmadiyah 


\section{PENDAHULUAN}

Jemaat Ahmadiyah Indonesia (JAI) telah berkembang dan menyebar di Indonesia sejak tahun 1920-an. Sejak awal kedatangannya mereka menghadapi banyak penolakan. Majelis Ulama Indonesia juga telah memfatwakan JAI sebagai kelompok sesat, melalui Musyawarah Nasional II tahun 1980 dan diperkuat dengan fatwa dalam Rapat Kerja Nasional tahun 1984 dan Musyawarah Nasional VII tahun 2005. Ajaran yang dianggap sesat terutama ajaran Ahmadiyah Lahore dianggap sesat oleh Ormas Islam Muhammadiyah antara lain berkaitan dengan kenabian, al-Mahdi, al-Masih, wahyu, dan khilafah. (Burhani \&Sudrajat, 2015).

Status sebagai kelompok sesat ini melahirkan kekerasan dan penganiayaan kepada JAI. Pemerintah telah berupaya mengatasi konflik dan kekerasan ini dengan mengeluarkan berbagai aturan. Namun, upaya tersebut belum mampu melindungi jemaat Ahmadiyah dari kekerasan. Kekerasan kepada jemaat Ahmadiyah justru mengalami eskalasi setiap tahun.

Beragam penolakan, penyerangan, dan penganiayaan terhadap JAI tidak menyurutkan semangat mereka untuk terus mempertahankan identitas keagamaannya. Alih-alih mengakui diri sebagai kelompok sesat kondisi tersebut justru semakin memperteguh keyakinan mereka kepada ajaran Ahmadiyah. Menjadi korban kekerasan seolah telah menjadi bagian dari ideologi Ahmadiyah dan mentransformasikan identitas mereka menjadi kelompok yang mendambakan cinta perdamaian dan jauh dari permusuhan (Love for all hatred for none). Di tempat lain, menurut Kamarudin \& Rahman (2018) Ahmadiyah tetap eksis dan mereka berupaya menyembunyikan paham dan ajaran yang mereka yakini di tengah masyarakat yang dipastikan akan menolak keberadaan mereka. Dalam kasus Ahmadiyah Manis Lor Kuningan, mreka memiliki karakteristik kepribadian yang peduli sosial kemanusiaan dengan kesiapan diri melakukan donor darah, donor mata, serta bantuan kemanusiaan terhadap korban bencana.(Saefullah, 2016). Dakwah kelompok ini dilakukan secara terorganisir dengan melibatkan seorang mubalig yang secara sukarela menyatakan kesiapannya. Sang mubalig mendapat dukungan finansial yang mumpuni. Semua beban biaya hidup mubalig dan keluarganya menjadi tanggungan organisasi JAI. Mubalig disekolahkan, disumpah, dan menetap di lingkungan di mana jamaah berada (Syukur, 2017)..

Salah satu daerah di mana JAI masih terus bisa eksis adalah Tasikmalaya. Di kota santri ini JAI tersebar di banyak lokasi seperti di Cihideung, Kawalu, Sukaraja, Cigalontang, Singaparna dan Salawu. Khusus di dua kecamatan terakhir jumlah JAI termasuk besar.

Dua daerah ini tidak luput dari tindak kekerasan. Peristiwa kekerasan yang dialami JAI seringkali diselesaikan melalui jalur dialog yang dimediasi oleh pemerintah dan aparat keamanan. Upaya mengatasi konflik dengan 
menggunakan jalur birokrasi dan keamanan di atas seringkali tidak optimal karena cenderung lebih melihat ke arah sisi eksternal atau upayanya dilakukan oleh kelompok di luar yang konflik yaitu Ahmadiyah dan masyarakat Islam. Masih jarang penyelesaian konflik secara internal yaitu inisiatif dari jemaat Ahmadiyah itu dan masyarakat Islam itu sendiri. Kondisi ini bisa menjadi penanda positif dalam upaya menghindari konflik dan kekerasan di masa yang akan datang. Peneliti tertarik untuk mengangkat masalah ini, yaitu strategi dakwah JAI dalam meminimalisir citra negatif dan menumbuhkan citra positif di masyarakat melalui kegiatan dakwah.

Penelitian tentang strategi Dakwah pernah diteliti oleh Yusuf (2013). Ia melakukan penelitian terhadap strategi dakawah bagi masyarakat Gampong. Hasil penelitiannya menunjukkan bahwa strategi Dakwah dapat mengambil wujud yang formal atau tindakan-tindakan yang membawa kemaslahatan dan patut diteladani. Kedua macam ajakan tersebut sering dibedakan dengan istilah dakwah bi allisan dan dakwah bi alhal. Dengan demikian setiap Muslim berpeluang untuk memberikan andilnya dalam pelaksanaan dakwah menurut kemampuan dan bidangnya masingmasing, terutama bagi masyarakat gampong di seluruh Aceh.

Sedangkan penelitian tentang Jamaah Ahmadiyah pernah diteliti oleh Andris, Mas'oed, dan Bagir (2014) tentang Identitas Jama'at Abmadiyab Indonesia dalam Konteks Multikultural. Hasil penelitannya menunjukkan bahwa penundaan layanan kartu ID untuk JAI di Kuningan tidak terbatas pada masalah identitas terkait doktrin teologis, tetapi juga dampak politik tawar-menawar di tingkat lokal terkait dengan kemenangan pemilihan umum, dan partai-partai lain terhadap pengaruh organisasi massa Islam yang ingin mempertahankan status quo dan kekuasaan. Negosiasi kepentingan antara pemerintah dan organisasi massa untuk menjadikan JAI sebagai objek kekuasaan menyebabkan diskriminasi terhadap JAI sebagai minoritas dalam memperoleh hak-hak mereka sebagai warga negara.

Penelitian ini berupaya menjawab pertanyaan: 1) Bagaimana hubungan JAI dengan umat Islam di Tasikmalaya? 2) Apa saja strategi dakwah yang dilakukan oleh JAI dalam meminimalisir citra diri negatif dan membangun citra diri positif di masyarakat? 3) Bagaimana hasil penerapan strategi dakwah JAI tersebut terhadap citra mereka di masyarakat?

Penelitian ini menggunakan pendekatan kualitatif dengan paradigma interpretif atau konstruktivisme dengan metode etnografi. Penekanan pada pilihan pendekatan etnografi, terkait dengan peristiwa yang menjadi obyek penelitian. Penelitian dilakukan di dua desa di Kabupaten Tasikmalaya yaitu Desa Tenjowaringin Salawu dan Desa Cipakat Singaparna. Sumber data yang digunakan dalam penelitian ini adalah informan sebagai responden. Sampel yang diambil sebagai informan menggunakan sampel bertujuan dan bergulir (purposive-snowball sample). Teknik pengumpulan data dilakukan dengan mengacu pada model penelitian etnografi Spradley (1980) melalui empat tahapan, 
yaitu Pengumpulan Data Etnografi (collecting ethnographic data), Pengumpulan data etnografi dilakukan melalui pendekatan teknik observasi partisipan, pembuatan Data Etnografi (making ethnographic data), analisis Data Etnografi (analyzing ethnographic data), dan mempertanyakan Data Etnografi (asking ethnographic questions).

Teori yang digunakan dalam penelitian ini adalah strategi dakwah, citra, dan dramaturgi. Strategi dapat diartikan sebagai suatu upaya yang dilakukan oleh seseorang atau organisasi untuk sampai pada tujuan. Sedangkan menurut Ahmad Warson Munawwir (1997), dari segi bahasa, dakwah berasal dari bahasa Arab "da'wah". Dakwah mempunyai tiga huruf asal, yaitu dal, 'ain, dan waw. Muhammad Hasan al- Jamsi (dalam Ismail \& Hotman, 2011: 28), mengungkapkan definisi dakwah menurut Syekh Ali Mahfuz yaitu mengajak manusia kepada kebaikan dan petunjuk Allah Swt., menyeru mereka kepada kebiasaan yang baik dan melarang mereka dari kebiasaan buruk supaya mendapatkan keberuntungan di dunia dan akhirat. Jadi, strategi dakwah adalah cara atau rencana dalam proses mengajak, dan menyeru ke arah kebaikan untuk melakukan perintah Allah dan meninggalkan larangan Allah Swt agar meraih keberhasilan dalam mencapai tujuan yaitu selamat di dunia dan akhirat.

Dalam strategi perlu inventarisasi masalah yaitu: 1) Analisis media, 2) Perpaduan komunikator (da'i) dengan media, 3) Penyusunan rencana dan pesan yang akan disampaikan, 4) Prosedur pelaksanaan kegiatan yang akan dilaksanakan (Suhandang, 2014: 105).

Sedangkan Citra (bahasa lnggris “image' atau gambar) adalah "The Picture in Ourbead' atau gambar yang ada dalam kepala kita. Gambar yang dimaksud adalah mental picture, yaitu gambar mental yang mengandung unsur positif dan negatif. Citra menurut Robert (dalam Rakhmat, 1999: 223) adalah keseluruhan informasi tentang dunia yang telah diolah, diorganisasikan, dan disimpan individu.

Beberapa jenis citra Menurut Frank Jefkins (Soemirat, 2004: 119) adalah : 1) Citra Cermin (mirror image), 2) Citra Kini (Current Image), 3) Citra Keinginan (wish image), Citra Perusahaan (corporate image), Citra Berlapis (multiple image), dan Citra penampilan (performance image). Citra dapat dibentuk melalui komunikasi, media pers, propaganda dan iklan.

\section{HASIL DAN PEMBAHASAN}

Kegiatan Ahmadiyah di Tenjowaringin dan Cipakat tidak terlepas dari kegiatan keislaman atau dakwah Islam. Dakwah Ahmadiyah didasarkan pada kegiatan organisasi yang telah terbentuk secara modern dan profesional. Organisasi dakwah Ahmadiyah telah berhasil tersebar ke 174 negara di seluruh dunia. Keberhasilan ini tidak bisa dilepaskan dari upaya dakwah organisatoris Ahmadiyah yang berada di bawah kepemimpinan Khalifah Al-Masib V, Mirza Masroor Ahmad. 
Kegiatan dakwah Ahmadiyah mengalami perbedaan antara sebelum keluar SKB 3 Menteri tahun 2008 dan setelahnya. Sebelum tahun 2008 kegiatan dakwah Ahmadiyah cukup mencolok dan bersifat ekspansif.

Kegiatan Ahmadiyah di desa Tenjowaringin lebih banyak dilakukan di masingmasing cabang, namun beberapa kegiatan biasa dilakukan bersama-sama oleh semua cabang karena lokasinya yang berdekatan dan mudah untuk koordinasi. Kegiatan Ahmadiyah ini digerakkan oleh pengurus cabang yang merupakan bagian dari struktur organisasi Ahmadiyah yang memiliki hirarki mulai dari tingkat pusat di London, tingkat nasional di Jakarta, tingkat wilayah Priangan Timur dan tingkat daerah Tasikmalaya. Pengurus cabang Ahmadiyah di Tenjowaringin sesuai dengan Anggaran Dasar dan Anggaran Rumah Tangga Tahun 1953 terdiri atas atas seorang ketua dibantu oleh sekretaris yaitu sekretaris khas, sekretaris bidang taligh (dakwah), bidang tarbiyat (pendidikan) dan bidang maal (harta). Bidang tabligh terdiri atas sekretaris Tabligh, sekretaris Isya'at, sekretaris Umur Kharijiah, sekretaris Dhiafat, sekretaris Sami wabasari, sekretaris Jaidad. Bidang Tarbiyat terdiri atas sekretaris Tarbiyat, sekretaris Ta'lim, sekretaris Umur Ammah, sekretaris Zira'at, sekretaris Sanatu-tijarat, sekre Waqfi Nau, sekretaris Rishta Nata. Adapun Bidang Maal terdiri atas sekretaris Maal, sekretaris Tabrik Jadid, sekretaris Waqfi Jadid, sekretaris Amin (Bendahara), sekretaris Muhasib (akuntan).

Selain pengurus cabang Jemaat Ahmadiyah di Tenjowaringin juga memiliki organisasi otonom atau badan-badan yang dikelompokkan berdasarkan umur jemaat, yaitu sebagai berikut: (a) Ansharullah. Organisasi di dalam Ahmadiyah yang beranggotakan bapak-bapak berumur 40 tahun ke atas. (b) Lajnah Imaillah (LI). Ini merupakan organisasi otonom dalam jemaat Ahmadiyah yang beranggotakan wanita berumur mulai 15 tahun ke atas yang dibagi ke dalam dua kelompok yaitu LI tua untuk wanita yang sudah menikah dan LI muda untuk wanita yang belum menikah. (c) Khuddam. Yaitu organisasi dalam jemaat Ahmadiyah yang memiliki anggota pemuda usia antara 15 sampai dengan 40 tahun. (d) Nashirat. Organisasi di dalam Ahmadiyah yang beranggotakan perempuan usia 7 sampai dengan 15 tahun. (e) Athfal. Adalah organisasi di bawah jemaat Ahmadiyah yang beranggotakan laki-laki berumur antara 7 sampai dengan 15 tahun. (f) Abna, yaitu organisasi di dalam jemaat Ahmadiyah yang beranggotakan anak laki-laki yang berumur di bawah 7 tahun. $(\mathrm{g})$ Banat, adalah organisasi dalam jemaat Ahmadiyah yang anggotanya terdiri atas anak perempuan di bawah 7 tahun.

Pengelompokan berdasarkan umur ini dimaksudkan untuk memudahkan dalam pembinaan anggota Ahmadiyah. Masing-masing organisasi otonom tersebut memiliki pengurus tersendiri. untuk khudam pengurusnya disebut Qaid, sedangkan untuk ansharullah disebut nazim dan untuk Lajnah Imaillah disebut pengurus cabang (Pengcab). Adapun Jemaat tingkat athfal, abna dan banath masuk dalam kepengurusan Qaid khuddam. Masing-masing kelompok tersebut dibagi lagi menjadi kelompok yang 
lebih kecil dengan jumlah maksimal 10 orang disebut saiq. Dengan kelompokkelompok kecil ini aktivitas jemaat bisa terpantau dengan lebih baik terutama dalam kegiatan pengajian, pengembangan kemampuan ilmu keagamaan seperti baca tulis al-Qur'an atau juga pembayaran chandah.

Pengurus Ahmadiyah di tiap cabang dipilih setiap 3 tahun sekali dan bisa dipilih untuk periode kedua. Di tingkat wilayah ini terdapat mubaligh pembina yang diutus oleh Ahmadiyah pusat dan diganti setiap 5 tahun. Saat ini mubaligh pembina di Tenjowaringin dipegang oleh Ridwan Ahmad.

Kegiatan yang dilakukan kelompok Ansharullah diantaranya adalah Ijtima' dan Da'i ilallah. Ijtima adalah kegiatan kumpulan bapak-bapak yang berisi pengajian, tahajud bersama, siraman rohani dengan ceramah-ceramah, jalan pagi, senam, pertandingan olah raga seperti tennis meja, badminton, volley atau sepak bola. Sedangkan kegiatan Da'i ilallah adalah kegiatan pelatihan menjadi da'i di kalangan bapak-bapak. Khusus untuk kelompok Ansharullah kegiatan mereka banyak dipublikasikan dalam majalah bulanan "Suara Ansharullah" yang diterbitkan oleh Majlis Ansharullah Ahmadiyah Indonesia di Jakarta.

Para pemuda Ahmadiyah yang tergabung dalam organisasi otonom Khuddam, setiap bulan mengadakan "Malam Khuddam" yaitu kegiatan pembinaan rohani selama satu malam dan dilanjutkan dengan tahajud bersama. Kegiatan ini diikuti oleh seluruh pemuda Ahmadiyah di Tenjowaringin dan dilaksanakan setiap bulan dengan lokasi yang berpindah-pindah bergiliran di antara cabang se-Tenjowaringin. Fungsi kegiatan "Malam Khuddam" adalah untuk memonitor dan mengontrol aktivitas serta kemampuan para pemuda Ahmadiyah dalam aspek keagamaan. Kegiatan lain yang para pemuda ikuti adalah wikari amal yaitu kegiatan bakti sosial seperti membersihkan pekarangan masjid dan donor darah untuk PMI. Jemaat Ahmadiyah di Tenjowaringin mendirikan Keluarga Donor Darah (KDD) Baitus Subhan sejak tahun 2009 sebagai bagian dari aksi kemanusiaan untuk memfasilitasi kebutuhan donor darah di PMI Tasikmalaya dan PMI Garut. Kegiatan donor darah di KDD Baitus Subhan dilakukan di Masjid Baitus Subhan kampung Citeguh setiap 3 bulan sekali dan terakhir dilakukan 12 Desember 2012 kemarin.(Hasil wawancara dengan Munawarman, Qaid Khuddam Wilayah Tenjowaringin tanggal 20 Desember 2012)

Para wanita Ahmadiyah yang tergabung dalam Lajnah Imaillab (LI) lebih banyak melaksanakan kegiatan sosial seperti memberi sumbangan korban bencana, sumbangan kepada anak asuh, dan lansia. Anggota LI ini memiliki majalah bulanan tersendiri yang disebut dengan "Suara Lajnah Imaillab". Sedangkan kegiatan untuk kelompok Nashirat diantaranya mengadakan wisata tarbiyat, berwisata ke suatu tempat sambil diisi dengan siraman rohani, dan mengadakan perlombaan nashirat antar cabang.

Kelompok athfal (anak-anak) mengikuti Kursus Pendidikan Agama (KPA) 
atau dikenal juga dengan Pesantren Kilat, yang diadakan pada waktu liburan anak sekolah. Kegiatan KPA ini juga diikuti oleh kelompok nashirat, abna dan banath. Khusus untuk Athfal di akhir tahun biasanya diadakan Pekan Athfal yang dimeriahkan dengan berbagai kegiatan seperti hapalan Juг 'Amma, Api unggun, dan mandi di sungai.

Selain kegiatan yang sifatnya kelompok sebagaimana diuraikan di atas, Ahmadiyah di Tenjowaringin juga sangat memperhatikan aspek pendidikan. Ahmadiyah memiliki lembaga pendidikan yang terbagi kepada sekolah umum dan sekolah agama atau madrasah. Sekolah umum yang dimiliki oleh Ahmadiyah Tenjowaringin terdiri atas PAUD, TK dan SLTA. Pendidikan Anak Usia Dini (PAUD) setingkat TK baru saja didirikan di Sukasari yaitu pada bulan Februari 2012 dengan izin dari Kementerian Pendidikan dan Kebudayaan Tasikmalaya. Sedangkan lembaga pendidikan setingkat SLTA Ahmadiyah telah lama memiliki SMU Plus alWahid di Wanasigra. SMU ini diresmikan oleh Khalifah Masih Hudur IV Mirza Thahir Ahmad tahun 2000 tatkala berkunjung ke Indonesia. Ini adalah salah satu SMU milik Ahmadiyah di Indonesia selain SMA Arif Rahman Hakim di Tangerang. Banyak siswa yang berasal dari daerah jauh seperti dari Jawa, Sulawesi dan Kalimantan yang bersekolah di sini. Mereka tinggal di asrama sekolah dan mendapatkan materi keahmadiyahan. Sekalipun milik Ahmadiyah, SMU ini bersifat terbuka, beberapa siswanya ada juga yang bukan Ahmadiyah. Mereka mendapatkan materi tentang keahmadiyahan melalui mata pelajaran muatan lokal.

Adapun Sekolah agama atau madrasah milik Ahmadiyah Tenjowaringin terdiri atas tiga tingkatan, yakni Madrasab Diniyah Awaliyah (tingkat dasar), Madrasah Diniyah Wustho (tingkat menengah) dan Jami'ah (tingkat perguruan tinggi). Madrasah Diniyah Awaliyah terdapat di setiap cabang, diperuntukkan khusus untuk anak-anak tingkat Sekolah Dasar. Kegiatannya dilaksanakan siang atau sore hari setelah mereka pulang dari sekolah dasar. Sedangkan Madrasah Diniyah Wustho hanya ada satu di cabang Wanasigra. Sekolah agama ini diperuntukkan bagi siswa tingkat SMP dan SMA. Adapun untuk tingkat Jam'iah (Perguruan Tinggi) di Tenjowaringin pernah didirikan Jami'ah Abmadiyah tahun 1974 sebagai kelanjutan dari madrasah Diniyah Wustho. Namun, lembaga pendidikan tinggi ini telah dipindahkan ke Bandung pada tahun 1983 dan dua tahun kemudian, 1985 pindah lagi ke kampus pusat Ahmadiyah di Parung Bogor.

Selain sekolah agama, Ahmadiyah di Tenjowaringin juga aktif dalam melaksanakan kegiatan pengajian bagi anggota dewasa. Pengajian dibagi menjadi pengajian mingguan atau dikenal juga dengan mu'awanah, pengajian bulanan, dan tahunan atau Jalsah Salanah. Pengajian Mu'awanah dilaksanakan setiap minggu sore bertempat di masjid Ahmadiyah diikuti oleh ibu-ibu dan remaja putri dengan pemateri berasal dari pengurus cabang dan terkadang mubaligh pembina Ahmadiyah Tenjowaringin. Dalam kegiatan ini biasanya juga diadakan penarikan iuran/chandah. 
Sedangkan pengajian untuk bapak-bapak biasanya diadakan bulanan yaitu setiap jum'at kedua setelah Jum'atan. Kegiatannya berisi ta'lim al-Qur'an, monitoring dan evaluasi bulanan kegiatan Ahmadiyah tingkat Ansharullah dan LI. Untuk kegiatan bulanan juga terdapat pengajian kelompok dan pengkajian buku-buku Ahmadiyah. Khusus untuk pengkajian buku ahmadiyah setiap tiga bulan sekali diadakan ujian bersifat open book (boleh membaca buku). Ujian ini dijadwalkan oleh pengurus pusat (Shadr) untuk masing-masing tingkatan dengan buku yang diujikan ditentukan dari pusat. Tujuan utama pengkajian buku ini adalah memonitor keaktifan jemaat Ahmadiyah dan juga mendorong mereka untuk membaca buku-buku Ahmadiyah. Setelah ujian pengurus akan mengulas buku-buku yang diujikan tersebut sehingga menambah pemahaman jemaat terhadap buku tersebut.

Adapun kegiatan tahunan Ahmadiyah disebut dengan Jalsab Salanah yaitu pertemuan tahunan yang diikuti oleh seluruh anggota Ahmadiyah. Jalsah Salanah tingkat dunia dilaksanakan di Qadian India dan dihadiri oleh perwakilan tiap negara. Sedangkan di Indonesia Jalsab Salanab dilaksanakan di Parung Bogor. Tahun 2000 pernah diadakan Jalsab Salanah sedunia di Parung Bogor yang dihadiri oleh Khalifah Masih keempat. Saat itu jemaat Ahmadiyah Tenjowaringin ikut hadir sebagai peserta. Sedangkan untuk tingkat cabang Jalsah Salanah di Tenjowaringin diselenggarakan selama 3 hari dan biasanya mengambil waktu libur sekolah, antara bulan Juni dan Juli. Jemaat berkumpul di masjid salah satu cabang untuk mendengarkan ceramah keagamaan yang diisi oleh pengurus Ahmadiyah maupun mubaligh pusat. Beberapa materi yang biasa disampaikan diantaranya materi tentang kisah Rasulullah, cara beribadah dan pengorbanan Rasulullah dalam dakwah. Terkadang mereka juga menonton siaran televisi Ahmadiyah MTA (Moslem Television Ahmadiyah) yang disiarkan langsung dari London Inggris.

Berbeda dengan aspek pendidikan, dalam aspek kegiatan ekonomi jemaat Ahmadiyah terlihat begitu begitu berkembang. Sekalipun dalam kepengurusan cabang terdapat Sekretaris Sanad wat Tijarat yaitu lembaga yang mengumpulkan data para pengusaha Ahmadiyah, namun tugas lembaga ini baru sampai mendata nama, kebutuhan modal dan pelatihan usahanya. Data tersebut kemudian dilaporkan ke pengurus pusat. Tahun 2005 pernah ada bantuan pendidikan dan pelatihan (diklat) bidang pertanian dan pinjaman dari pengurus Ahmadiyah pusat. Pengembalian cicilan dilakukan sebanyak 4-5 kali dalam bentuk perjanjian yang dimonitor secara berkala. Hanya saja beberapa tahun terakhir belum ada lagi kucuran dana tersebut sehingga aktivitas kegiatan ekonomi ini tidak lagi kelihatan. Untuk lembaga usaha yang bergerak di bawah organisasi Ahmadiyah sampai saat ini belum ada. Jadi, dana untuk menghidupkan organisasi semata-mata berasal dari pembayaran Chandab/iuran bulanan. 


\section{Hubungan JAI dengan Umat Islam}

Hubungan JAI dengan masyarakat khususnya umat Islam selain Ahmadiyah di desa Tenjowaringin Salawu maupun di Desa Cipakat Singaparna cukup baik. Hanya saja letupan- letupan beberapa kali terjadi utamanya disebabkan oleh provokasi dari kelompok di luar masyarakat dua desa tersebut.

Sejak awal kehadirannya di Tenjowaringin sampai tahun 2005 sangat jarang terdengar bentrokan di antara warga Ahmadiyah dan warga NU di desa ini. Namun sejak 2008 sampai 2013, terjadi beberapa kali penyerangan, pembakaran masjid dan rumah warga. Kasus terakhir penyerangan terjadi pada tanggal 15 Mei 2013, tatkala jemaat Ahmadiyah melaksanakan pertemuan tahunan (Jalsah Salanah).

Adapun JAI di Desa Cipakat berlokasi di Kecamatan Singaparna dengan pusat kegiatan Jemaat Ahmadiyah di masjid Baiturrahim. Lokasi sekretariat organisasi JAI tersebut berdekatan dengan pesantren Cipasung yang berafiliasi dengan Nahdhatul Ulama, kurang lebih berjarak sekitar 100 meter. Sampai saat ini anggota jemaat Ahmadiyah di Singaparna mencapai 500 orang dengan pusat kegiatan di Masjid Baiturrahim. Sejak tahun 1960an sering terjadi perdebatan antara jemaat Ahmadiyah dengan tokoh ulama Singaparna seperti dengan Haji Anwar sanusi yang Wahabi. Namun perdebatan itu hanya terjadi di forum setelah selesai tidak ada permusuhan di antara mereka. Sejak tahun 2008, jemaat Ahamdiyah di Desa Cipakat ini mengalami beberapa kali penyerangan. Tahun 2011 masjid Mahmudi di Jalan Nagarawangi dirusak dan dibakar ormas Islam. sampai saat ini masjid tersebut tidak pernah bisa difungsikan kembali karena ditolak oleh warga sekitar. Tahun 2012 Masjid Baiturrahim juga pernah dirusak, namun kembali dibangun oleh jemaat Ahmadiyah.

\section{Strategi Dakwah JAI}

Ahmadiyah sebagai organisasi memiliki misi dakwah dalam rangka menyebarluaskan ajarannya. Dalam pandangan Ahmadiyah dakwah wajib dilaksanakan sesuai dengan perintah Al-Qur'an surat An-Nahl ayat 126. Anggota Ahmadiyah semuanya wajib berdakwah, sehingga begitu pentingnya dalam dalam Ahmadiyah tercantum dalam motto "tiada hari tanpa tabligh".

Ahmadiyah menyebut konsep dakwahnya sebagai dakwah ilallah, mengajak orang untuk bergabung kepada ajaran Islam murni dalam pemahamannya. Konsep dakwah ini terbagi kepada tiga bagian yaitu: (a) Dakwah bil kalam, yaitu dakwah dengan melalui pembicaraan, dialog, diskusi, seminar dan lain-lainnya. (b) Dakwah bil Qolam yaitu dakwah melalui tulisan seperti penerbitan buku, majalah dan media cetak lainnya. (c) Dakwah bil hal, yaitu cara dakwah melalui kepribadian atau pembawaan mubaligh Ahmadiyah yang berprilaku, bersikap dan bertindak secara sopan dan baik. Seorang mubaligh Ahmadi harus menampilkan sikap sopan santun ketika berdakwah. 
Berdasarkan tempat dan wilayah dakwah para mubaligh Ahmadiyah terbagi menjadi dua yaitu intiqoli dan Maqomi. Intiqoli adalah dakwah di wilayah orang lain dengan berpindah atau dengan melakukan perjalanan dalam masa tertentu untuk menyebarkan ajaran Ahmadiyah. Masyarakat yang tinggal di daerah tempat tinggalnya didatangi dan diajak berkomunikasi, sehingga terjalin kerjasama antara mubaligh Ahmadiyah sebagai pendatang dengan masyarakat setempat sebagai tuan rumah. Sedangkan maqomi artinya dakwah di tempatnya sendiri. Setiap orang yang bekerja dianjurkan untuk meluangkan waktu beberapa jam setiap harinya untuk bersilaturahmi dengan masyarakat yang tinggal di sekitar tempat tinggalnya untuk mendakwahkan ajaran Ahmadiyah. Prinsip dakwah Ahmadiyah adalah menyampaikan rahmat Rasulullah kepada seluruh umat Islam.

Metode dakwah Ahmadiyah juga merujuk kepada metode Al-Qur'an yaitu surat An-Nahl: 126 yaitu secara bertahap dan penuh kesabaran yaitu dengan memanggil kepada jalan Tuhan dengan hikmah/kebijaksanaan. Dalam tahapan ini mubaligh ahmadi perlu mengetahui keinginan mad'unya, kemudian dicari persamaan pendapat dan tujuan. Tahapan kedua member nasihat yang baik dengan menunjukkan kebaikan diri mubaligh Ahmadi dan jamaah Ahmadiyah dan terakhir bila sudah ada dalam jangkauan dan lingkungan Ahmadiyah baru dikemukakan dalil dan tukar pikiran dengan mad'u melalui cara yang sebaik-baiknya.

Dalam pandangan Ahmadiyah menggunakan dalil kepada orang-orang nonAhmadi sudah dianggap tidak berguna karena mereka jelas-jelas menolak ajaran Ahmadiyah. Maka cara baru yang mereka lakukan dengan mendekati para pemuda serta orang-orang yang mengharapkan kebaikan, kemajuan, kesejahteraan dan perdamaian dalam masyarakat. Diberikan dulu penerangan kepada orang-orang nonAhmadiyah tentang tujuan jemaat Ahmadiyah dan tujuan agama Islam sebenarnya, bila sudah ada kebersamaan dan rasa simpati baru dikemukakan dalil-dalilnya. Dengan cara tersebut diharapkan dapat menarik orang-orang non-Ahmadi untuk bergabung dengan jemaat Ahmadiyah.

Metode dakwah Ahmadiyah secara garis besar terbagi kepada dua metode. Pertama, dakwah internal, yaitu dakwah bagi para pengikutnya dalam rangka menjaga kontinuitas kerja dakwah Ahmadiyah dan dakwah secara eksternal yaitu dakwah kepada masyarakat umum yang belum tergabung dalam jemaat Ahmadiyah. Metode dakwah internal jemaat Ahmadiyah dikenal dengan istilah Tarbiyat. Tarbiyat adalah mendakwahkan ajaran Islam seperti pengamalan rukun Islam dan rukun Iman. Dakwah internal Ahmadiyah berguna untuk menyempurnakan tingkat keimanan dan ketakwaan diri sendiri kepada Allah Swt. Setiap anggota Ahmadiyah harus bias menjadi da'i dalam internal Ahmadiyah yaitu selalu mengingatkan jemaat yang lainnya. Misalnya bila ada anggota jemaat Ahmadi yang shalatnya tidak benar maka harus memberi peringatan. Dakwah internal dilakukan oleh badan-badan dalam organisasi Ahmadiyah seperti athfalul Ahmadiyah, Nashiratul Ahmadiyah, khudamul 
Ahmadiyah, lajnah Imaillah Ahmadiyah.

Pada proses dakwah internal badan-badan organisasi Ahmadiyah terbagi menjadi tujuh kelompok. Dengan susunan sebagai berikut:

Kelompok I : untuk anak usia sampai 7 tahun

Kelompok II : untuk anak usia 7-10 tahun

Kelompok III : untuk anak usia 10-13 tahun

Kelompok IV : untuk anak usia 13-15 tahun

Kelompok V : untuk anak usia 15-17 tahun

Kelompok VI : untuk anak usia 17-19 tahun

Kelompok VII : untuk anak usia 19-21 tahun

Untuk orang dewasa lebih dari 21 tahun pendidikannya berupa pemantapan.

Kelompok I dalam Ahmadiyah disebut abna (anak laki-laki) dan banat (anak perempuan). Pada kelompok ini pendidikan yang harus mereka pelajari adalah Yassarnal Qur'an, ibadah/shalat dan doa, serta rukun Islam dan rukun Iman. Athfalul Ahmadiyah adalah kelompok anak dalam Ahmadiyah usia tujuh tahun sampai 13 tahun. Kelompok ini berada di bawah pimpinan Majlis Khuddamul Ahmadiyah. Kelompok tarbiyat yang termasuk dalam badan Athfalul Ahmadiyah adalah kelompok II-IV. Pada kelompok II, materi yang dipelajari adalah Al-Qur'an, ibadah, sejarah Islam Ahmadiyah, rukun Islam dan rukun Iman, akhlak fadhilah, dan pengurbanan dalam Islam. Pada kelompok III materinya sama dengan kelompok II hanya ditambah dengan mata pelajaran hadits. Untuk kelompok IV, materinya sama dengan kelompok III hanya ditambah dengan materi fiqih dan sajak-sajak Masih mau'ud a.s.

Nashiratul Ahmadiyah terdiri dari anak-anak perempuan Ahmadiyah dari usia 7 tahun sampai 15 tahun. Badan ini bertugas mendidik anak-anak perempuan Ahmadiyah di bawah pengawasan Lajnah Imaillah. Badan ini berusaha mengarahkan anak-anak untuk berakhlak yang baik. Untuk anak-anak diadakan pertemuan dan perlombaan seperti perlombaan berpidato, membaca nadom-nadom dan pengetahuan agama. Diadakan juga ujian bagi mereka. Untuk anak yang mendapatkan nilai tinggi dalam ujian diberikan hadiah. Nashiratul Ahmadiyah juga mengadakan salanah Ijtima setiap tahun, waktunya bersamaan dengan Jalsah Salanah Lajnah Imaillah. Kelompok-kelompok yang ada dalam badan ini sama seperti yang terdapat dalam badan Athfalul Ahmadiyah dengan materi pelajaran yang juga sama. hanya saja badan ini khusus untuk anak-anak perempuan.

Khudamul Ahmadiyah terdiri atas pemuda-pemuda Ahmadiyah yang berusia 15-40 tahun. Badan ini mengatur pemuda Ahmadiyah. Pada awal terbentuknya badan ini pernah dijabat oleh putra Hazrat Khalifah Masih II ra yaitu Mirza Tahir Ahmad. Badan ini bertugas mendidik pemuda Ahmadiyah seperti menolong orang miskin, orang tidak mampu dari agama apa saja. Kelompok-kelompok tarbiyat yang 
termasuk dalam badan ini adalah kelompok V-VII. Pada kelompok V materi yang dipelajari adalah al-Qur'an, ibadah, sejarah Islam dan Ahmadiyah, akhlak fadhilah, hadits, sajak-sajak Hazrah masih mau'ud, fiqih, dan pengorbanan dalam Islam. Untuk kelompok VI materinya sama dengan kelompok V hanya saja ditambah materi perbandingan agama, tiga masalah penting, tanda-tanda akhir zaman, dan khabar suka. Pada kelompok VII materinya sama dengan kelompok VI hanya dilengkapi lagi dengan materi mengenai filsafat ajaran Islam, masalah Isra mi'raj, masalah nabi Adam, Islam dan Komunisme.

Lajnah Imaillah berupa badan atau kelompok yang terdiri dari para wanita Ahmadiyah berusia lima belas tahun ke atas. Badan ini berupaya mendidik kaum wanita Ahmadiyah. Kelompok-kelompok yang termasuk dalam badan ini sama dengan yang ada dalam badan Khudamul Ahmadiyah dan materi tarbiyatnya pun sama. Hal yang membedakannya hanya badan ini khusus untuk kaum wanita. Lajnah Imaillah melakukan kegiatan dakwah setiap minggu dan yang mengisi adalah mubaligh bisa laki-laki atau perempuan. Jika mubalighnya laki-laki harus diberi pembatas antara mubaligh laki-laki dengan jemaat wanita.

Ansharullah, adalah badan Ahmadiyah yang mengatur orang-orang Ahmadi berusia 40 tahun ke atas. Jemaat Ahmadiyah yang sudah dewasa dengan usia lebih dari 21 tahun ke atas pendidikannya berupa pemantapan. Pemantapannya ini misalnya sudah berkeluarga dan mempunyai banyak anak harus mendidik putraputri mereka. Petunjuknya berupa bangun pada dini hari dengan tidak lupa mendirikan shalat tahajud. Sang bapak harus mendirikan shalat berjamaah, ibu di rumah harus menjalankan shalat pada waktunya. Membaca Al-Qur'an setiap hari dengan suara keras agar dapat didengar dan dicontoh oleh anak-anak dan memelihara anak-anak agar tetap bersih.

Selain itu juga memberikan anak-anak makan pada waktu yang telah ditentukan sesuai takaran. Memberikan anak suntikan imunisasi pada waktu yang ditentukan, menggunakan bahasa yang sopan terhadap anak-anak. Dilarang menceritakan kisah menyeramkan kepada anak-anak. Setiap bulan paling sedikit satu kali menulis permohonan doa dari mereka kepada huzur atba. Orang tua harus menelaah buku-buku tarbiyat yaitu Karniyabi ki Raabey (Jalan kesuksesan), Minhajuttalibin (jalan para pencari kebenaran). Allah ki Baatey I dan II (Firman Allah I dan II), Bachung ki Parwarish (teladan untuk anak-anak), Waqf-e-now (tuntunan bagi orang tua), konpal (taman surga), Ghunca (cerita lucu) dan Gul (kebun). Memberitahukan kepada anak-anak bahwa mereka adalah mujahid atau pejuang dan merupakan anak yang baik. Memberikan sesuatu kepada anak berupa uang atau barang dalam jumlah tertentu, lalu menekankan mereka untuk mau memberikan sebagian dari uang/barang tersebut bagi orang lain. Mengawasi anak-anak ketika sedang bermain, dan senantiasa mendoakan mereka.

Kegiatan lainnya adalah kursus pendidikan agama selama tiga hari sampai dua 
minggu serta mendapat sertifikat untuk jenjang pendidikan sekolah dasar sampai dengan perguruan tinggi. Kursus pendidikan agama dilakukan oleh Lajnah Imaillah, Ansharullah, Khudamul Ahmadiyah, Athfalul Ahmadiyah, Nashiratul Ahmadiyah, Banathul Ahmadiyah. Mu'awanah adalah kegiatan tarbiyat yang dilakukan setiap minggu dalam sebulan untuk kalangan ibu-ibu. Masalah-masalah yang dibicarakan mengenai dirasah Islamiyah baik dari segi organisasi, rumah tangga dan lain-lain. Dalam kegiatan mu'awanah mubalighnya adalah wanita. Durasi waktunya 1-2 jam, dimulai dengan tilawat al-Qur'an setelah itu janji Lajnah Imaillah, presentasi narasumber dan tanya jawab.

Bila dilihat berdasarkan waktu, kegiatan internal Ahmadiyah yang dilakukan tiap tahun oleh seluruh anggota jamaah adalah Jalsah Salanah, kegiatan ini bertujuan untuk mendidik anggota tarbiyat dan tabligh setahun sekali dan juga sebagai sarana untuk menambah pengalaman mereka. Selain itu juga, sebagai sarana pertemuan tahunan antara anggota jemaat Ahmadiyah. Dalam kegiatan dakwah bulanan ada yang namanya ta'lim tarbiyat dimana badan-badan dalam organisasi Ahmadiyah Indonesia semuanya berkumpul dan mengadakan tanya jawab atau diskusi. Kegiatan dakwah tahunan lainnya disebut ijtima'. Kegiatan ini dilakukan setiap tahun oleh badan organisasi jemaat Ahmadiyah Indonesia. Kegiatannya berupa jalan santai misalnya ke pegunungan dengan tidak lupa memberikan pendidikan tarbiyat agama seperti shalat tahajud. Setiap minggu Ahmadiyah mengadakan kegiatan shalat tahajud bersama. Untuk para mubaligh ada jadwal shalat tahajudnya. Jumlah rakaat yang digunakan adalah 11 orang terdiri atas 8 rakaat dan witir 3 rakaat. Ada juga puasa nafal atau biasa disebut puasa senin dan kamis.

Strategi dakwah yang dilakukan jemaat Ahmadiyah dilakukan dalam tiga kegiatan yaitu komunikasi melalui kegiatan Rabtah, kerjasama melalui wikari amal, dan Pendidikan melalui lembaga Tarbiyah/Sekolah. (a). Komunikasi Melalui Rabtah Adalah strategi dakwah yang dilakukan oleh jemaat Ahmadiyah diawali dengan melakukan komunikasi melalui kegiatan Rabtah. Rabtab adalah kegiatan silaturahmi pengurus Ahmadiyah dengan pejabat pemerintah, ulama tokoh masyarakat dan cendekia. Kegiatan ini dilakukan untuk memperkuat tali silaturahmi dan komunikasi diantara jemaat Ahmadiyah dengan tokoh di luar Ahmadiyah sekaligus juga menepis isu-isu negatif dan provokatif yang ditujukan kepada jemaat Ahmadiyah yang membentuk citra buruk terhadap Ahmadiyah dengan tanpa dasar yang kuat (Sitarah, 2013).

Kegiatan rabtah dilakukan secara terencana. Sesuai dengan tujuan organisasi Ahmadiyah dimana hendak memperkenalkan Ahmadiyah, pengurus Ahmadiyah dan anggota Ahmadiyah kepada pihak yang akan diajak berkomunikasi. Sebelum pelaksanaan rabtah diadakan terlebih dahulu rapat di tingkat pengurus. Mengikuti kerangka The Six M's Management dari Sukarno (dalam Suhandang, 2014: 103) maka bisa diketahui proses strategi dakwah JAI dalam rabtah yaitu 1) penentuan 
orang-orang (men) yang akan melaksanakan rabtah. 2) persiapan biaya (money) rabtah. 3) persiapan bahan (material), ketika pelaksanaan kegiatan rabtah, 4) persiapan peralatan (machine), 5) penentuan metode (method) yang akan dilakukan, dan Penentuan target (market) kegiatan rabtah.

Adapun kegiatan komunikasi Rabtah Ahmadiyah ini berdasarkan hasil observasi dan wawancara dapat dikategoriasasikan kepada tiga yaitu komunikasi level atas atau rabtah dengan pejabat pemerintah, komunikasi level sejajar atau rabtah dengan para ulama dan cendekia, serta komunikasi level bawah atau rabtah dengan masyarakat. 1) Komunikasi level atas (Rabtah pejabat pemerintah) Kunjungan jemaat Ahmadiyah kepada pejabat pemerintah sebagai level atas dilakukan untuk dua tujuan yaitu pertama untuk membangun komunikasi dengan pejabat baru yang mulai bertugas di daerah tersebut. Kegiatan ini misalnya dilakukan dalam bentuk kunjungan kepada Bupati, Camat, Kepala Polsek, Kepala Polres, Danramil dan Kodim yang baru yang menjabat di Tenjowaringin, Singaparna maupun Tasikmalaya. Kedua, rabtah dilakukan dalam rangka mencari penyelesaian konflik yang dihadapi Ahmadiyah. Jemaat Ahmadiyah di Tasikmalaya beberapa kali pernah mengalami penyerangan oleh ormas Islam tertentu. 2) Komunikasi level sejajar, atau rabtah dengan Ulama dan Cendekia. Kegiatan komunikasi rabtah ini dilakukan jemaat Ahmadiyah dengan mengunjungi para tokoh agama, ulama dan pimpinan pondok pesantren yang ada di Tasikmalaya. 3) Komunikasi level bawah atau Rabtah dengan masyarakat Komunikasi di level bawah ini dilakkan dengan berbagai komponen masyarakat. Misalnya JAI Tenjowaringin sering melakukan Rabtab kepada mahasiswa PMII, pemuda GP Anshor, Lembaga Swadaya Masyarakat (LSM/NGO)

b. Kerjasama Melalui Wikeari amal

JAI memiliki kegiatan dakwah dalam bentuk kerjasama. Artinya kegiatan ini dilakukan secara terbuka bersama-sama dengan unsur masyarakat di luar JAI. Hal ini bisa dilihat dari konsep Wikari amal atau kegiatan Ahmadiyah yang bersifat pengkhidmatan sosial. Wikari amal menjadi bagian dari program kerja organisasi Ahmadiyah dengan tujuan untuk membantu masyarakat sekitar atau masyarakat yang membutuhkan bantuan.

Kegiatan wikari amal di jemaat Ahmadiyah terbagi menjadi dua jenis: wikari amal untuk kepentingan jemaat Ahmadiyah dan wikari amal untuk kepentingan masyarakat umum. Wikari amal untuk kepentingan jemaat Ahmadiyah artinya kegiatan sosial yang dikhususkan bagi kebutuhan anggota atau organisasi yang perlu dilakukan secara bergotong royong. Adapun wikari amal untuk kepentingan masyarakat umum adalah kegiatan sosial yang diikuti oleh jemaat Ahmadiyah dengan tujuan untuk kepentingan masyarakat secara umum.

Kegiatan wikari amal dilakukan oleh jemaat Ahmadiyah untuk menepis anggapan bahwa kelompok Ahmadiyah adalah kelompok eksklusif. Kegiatan wikari 
amal dari segi prosesnya dibagi menjadi dua kategori, pertama, kegiatan Wikari amal pusat yaitu kegiatan yang dikoordinir oleh pengurus pusat JAI, pengurus cabang hanya mengirimkan utusan untuk ikut berpartisipasi dalam kegiatan tersebut. kegiatan ini dikoordinir oleh pengurus pusat melalui organisasi bernama bumanity first yang bergerak dalam bidang kemanusiaan. Sedangkan kegiatan bantuan bencana alam dikoordinir oleh pengurus pusat melalui kerjasama dengan Aksi Cepat Tanggap (ACT).

Kedua kegiatan Wikari amal cabang yaitu kegiatan yang dilaksanakan dan dikoordinir oleh pengurus cabang jemaat Ahmadiyah. Kegiatan ini misalnya dalam bentuk kerja bakti, donor darah, dan pengobatan masal.

Berikut perbedaan Wikari amal di Tenjowaringin dan Singaparna. Wikari Amal di Tenjowaringin Di Tenjowaringin kegiatan wikari amal dalam bentuk kerja bakti, pengobatan massal, dan donor darah. Kegiatan kerja bakti diadakan oleh pemerintah desa. Karena pengurus desa berasal dari jemaat Ahmadiyah maka mereka menjadi pelopor dalam beberapa kegiatan kerja bakti di desa ini.

Wikari Amal di Singaparna Posisi jemaat Ahmadiyah yang minoritas di Singparna khususnya di Desa Cipakat menjadikan kegiatan wikari amal mereka sedikit berbeda dengan kegiatan yang dilakukan di tenjowaringin. Dalam kegiatan donor darah dan pengobatan massal misalnya pengurus Ahmadiyah Singaparna melaksanakannya tanpa menunjukan nama Ahmadiyah. Pengurus Ahmadiyah melakukan kegiatan tersebut tidak secara khusus. Hal ini terjadi karena keterbatasan SDM dan juga mengantisipasi hal-hal yang tidak diinginkan.

c. Pendidikan atau Tarbiyah/Sekolah

Strategi dakwah JAI lainnya adalah pembukaan lembaga pendidikan yang bisa diakses oleh orang-orang di luar Ahmadiyah. Kegiatan Dakwah sosial ini dilakukan oleh jemaat Ahmadiyah melalui pendirian lembaga pendidikan formal. Jemaat Ahmadiyah mendirikan beberapa sekolah yang diperuntukan untuk warga Ahmadiyah namun juga terbuka kepada masyarakat umum. Misalnya di Tenjowaringin, JAI memiliki lembaga pendidikan mulai dari tingkat TK, PAUD, SMP, sampai SMA Al-Wahid.

\section{Citra Diri Jemaat Ahmadiyah}

Penerapan Strategi dakwah yang dilakukan oleh JAI mampu membentuk citra diri positif mereka di masyarakat sesuai dengan yang diharapkan oleh jemaah maupun pengurus organisasi Ahmadiyah. Citra Jemaat Ahmadiyah terbentuk oleh pemikiran etnosentrime, prasangka, dan stereotip dalam bentuk kebencian (hate speech). Mereka dianggap sebagai kelompok yang sesat dan keluar dari agama Islam. Pemikiran ini melahirkan citra Ahmadiyah yang buruk. Citra buruk Ahmadiyah ini terus disebarluaskan oleh media massa dan juga tokoh-tokoh agama yang tidak suka kepada Ahmadiyah. Setelah melalui kegiatan dakwah citra 
buruk tersebut sedikit demi sedikit bisa dikikis sekalipun belum maksimal.

Berdasarkan hasil penelitian didapatkan bahwa melalui kegiatan komunikasi rabtah, para pejabat pemerintah memberikan respon positif sekaligus juga terbuka komunikasi dalam menyelesaikan masalah berkaitan dengan isu tentang Ahmadiyah.

Beberapa kasus bisa diselesaikan dengan baik berkat kegiatan silaturahmi yang cukup intens dengan Camat, Kepala Polsek, Danramil dan kepala KUA. Misalnya dalam kasus penolakan pernikahan warga Ahmadi oleh KUA. Melalui komunikasi dan desakan akhirnya warga Ahmadi kembali bisa mendapatkan haknya untuk dicatatkan oleh KUA.

Citra positif juga didapatkan oleh Ahmadiyah melalui kegiatan kerjasama wikari amal, pihak yang bekerjasama dengan Ahmadiyah dalam kegiatan sosial memberikan penilaian positif kepada Ahmadiyah. Ini misalnya yang disampaikan oleh pengurus PMI cabang Garut dan Tasikmalaya (wawancara 25/7/2015) yang menilai anggota Ahmadiyah sangat baik hati bersedia membantu sesama yang membutuhkan bantuan darah dengan rutin mendonorkan darahnya di PMI.

Kegiatan komunikasi Tarbiyah juga cukup positif memberikan citra baik bagi jemaat Ahmadiyah. Orang tua siswa yang menyekolahkan anaknya ke lembaga pendidikan milik Ahmadiyah memberikan respon positif berkaitan dengan ajaran Ahmadiyah. sekalipun mereka tidak menyetujui beberapa keyakinan Ahmadiyah, namun hal itu menutup mereka untuk memberikan kepercayaan anaknya untuk dididik oleh jemaat Ahmadiyah.

\section{PENUTUP}

Berdasarkan penjelasan di atas dapat disimpulkan bahwa Hubungan JAI dengan masyarakat khususnya umat Islam non-Ahmadiyah di desa Tenjowaringin Salawu maupun di Desa Cipakat Singaparna Tasikmalaya cukup baik. Beberapa kali muncul letupan-letupan yang disebabkan oleh provokasi dari kelompok di luar masyarakat dua desa tersebut. Baik di Tenjowaringin maupun di Cipakat masjid milik JAI terpisah dari masjid NU, hal ini sering menjadi penyebab terjadinya letupan yaitu penentangan pendirian atau renovasi masjid oleh JAI seperti misalnya masjid di Tenjowaringin yang sedang dibangun pernah dihentikan oleh aparat pemerintah atas permintaan warga. Demikian juga masjid Mahmudi di Cipakat dihentikan pembangunannya karena jumlah jamaah Ahmadiyah dianggap sudah berkurang. Sekalipun banyak letupan, namun hal itu tidak menjadikan JAI menjadi jauh dari masyarakat sekitarnya.

Strategi Dakwah JAI yang dilakukan jemaat Ahmadiyah dilakukan dalam tiga kegiatan yaitu komunikasi melalui kegiatan Rabtab, kerjasama melalui wikari amal, dan pendidikan melalui lembaga Tarbiyah/Sekolah. Strategi dakwah yang dilakukan melalui komunikasi Rabtah dilakukan JAI melalui pemenuhan The 
Six M's Management dari Sukarno yaitu, penentuan orang-orang, persiapan biaya, persiapan bahan, persiapan peralatan, penentuan metode, dan Penentuan target rabtah. Kegiatan rabtah dilakukan melalui tiga bentuk komunikasi yaitu komunikasi level atas atau rabtah dengan pejabat pemerintah, komunikasi level sejajar atau rabtah dengan para ulama dan cendekia, serta komunikasi level bawah atau rabtah dengan masyarakat. Kegiatan kerjasama melalui wikari amal dilakukan jemaat Ahmadiyah melalui dua jenis, yaitu wikari amal untuk kepentingan jemaat Ahmadiyah dan wikeari amal untuk kepentingan masyarakat umum. Sedangkan komunikasi pendidikan dilakukan melalui pendirian lembaga sekolah yang bisa diakses oleh seluruh masyarakat termasuk non-Ahmadiyah.

Hasil Penerapan Strategi Dakwah JAI mampu membentuk citra diri positif mereka di masyarakat sesuai dengan yang diharapkan oleh jemaah maupun pengurus organisasi Ahmadiyah. Melalui kegiatan komunikasi rabtah, para pejabat pemerintah memberikan respon positif sekaligus juga terbuka komunikasi dalam menyelesaikan masalah berkaitan dengan isu tentang Ahmadiyah. Citra positif juga didapatkan oleh Ahmadiyah melalui kegiatan kerjasama wikari amal, pihak yang bekerjasama dengan Ahmadiyah dalam kegiatan sosial memberikan penilaian positif kepada Ahmadiyah. Kegiatan komunikasi Tarbiyah juga cukup positif memberikan citra baik bagi jemaat Ahmadiyah, khususnya dari orang tua anak yang sekolah di lembaga pendidikan Ahmadiyah.

\section{DAFTAR PUSTAKA}

Andries, F.F. dkk. (2014) Identitas Jemaah Ahmadiyah Indonesia Dalam Konteks Multikultural, Humaniora, 26 (2): 117-133.

Burhani, M. \& Sudrajat, A.(2015) . Pandangan Muhammadiyah terhadap Ajaran Ahmadiyah Lahore di Yogyakarta (1924 - 1945). Jurnal Universitas Negeri Yogyakarta, 5(8),

Fatoni,U. (2014). Transformasi Identitas Ahmadiyah setelah Keluar dari Ahmadiyah. Disertasi . Bandung: Unpad

Fatoni, U.(2014). Respon Da'i Terhadap Gerakan Jemaat Ahmadiyah Indonesia(JAI)di Tenjowaringin Tasikmalaya. Jurnal Dakwah, 15(1), 49-65.

Ismail, I. \& Hotman, P. (2011). Filsafat Dakwah: Rekayasa Membangun Agama Dan Peradabn Islam. Jakarta: Fajar Interpratama Offset.

Munawir, A.W. ( 1997). Al-Munawir-Kamus Arab-Indonesia. Surabaya: Pustaka Progresif.

Mustamin, K \& Rahman, M.G. (2018). Ahmadiyah dalam Islam (Studi Keagamaan di Kota Gorontalo). Jurnal Pemikiran Konstruktif Bidang Filsafat dan Dakwah, 18 (2), 26-41.

Saefullah, C. (2016). Ahmadiyah: Perdebatan Teologis dan Masa Depan Dakwah . ANID A Aktualisasi Nuansa Ilmu Dakwah, 15 (2), 225-247. 
U. Fatoni

Soemirat, S. (2004). Dasar-DasarPublic Relation,Bandung: RemajaRosdakarya.

Suhandang, K. (2014). Strategi Dakwah, Bandung: PT. Rosdakarya.

Spradley, J.(1980). Participant Observation. New York: Holt Rinehart and Winston.

Syukur, A. (2017). Gerakan Dakwah Ahmadiyah (Studi Kasus Jamaah Ahmadiyah Indonesia Desa Manis Lor Kecamatan Jalaksana Kabupaten Kuningan Jawa Barat). Kalimah, 15(2), 169-189.

Yusuf, M. (2009) Strategi Dakwah bagi Masyarakat Gampong, Jurnal Mentari Universitas Mubammadiyah Aceh, 12 (1). 